\begin{tabular}{|cc|}
\hline MOPED & LAWN MOWER \\
FUEL & COMBUSTION \\
BENZENE & ALKYLBENZENES \\
ALKENES & ALKANES \\
ANALYSIS & EXPOSURE \\
\hline
\end{tabular}

Open access manuscript version of Chemosphere 27 (1993) 1719-1728 doi:10.1016/0045-6535(93)90152-U

\title{
Volatile hydrocarbons in exhaust from alkylate-based petrol
}

\author{
Ulf Östermark and Göran Petersson
}

A preceding study was made for petrol vapors.

Proportions of hydrocarbons have also been reported for traffic emissions and road tunnels. 


\title{
VOLATILE HYDROCARBONS IN EXHAUST FROM ALKYLATE-BASED PETROL
}

\author{
Ulf Östermark and Göran Petersson* \\ Department of Chemical Environmental Science \\ Chalmers University of Technology \\ 41296 Göteborg, Sweden
}

\begin{abstract}
The non-methane hydrocarbon composition was studied for emissions from new alkylate-based fuels marketed for applications of special concern to human health and the environment. Proportions of 27 selected $\mathrm{C}_{2}-\mathrm{C}_{8}$ hydrocarbons were determined in moped exhaust for an alkylatebased fuel and a conventional reformate-based fuel. Samples were taken on an adsorbent cartridge behind the moped during driving, and were analyzed by thermal desorption and gas chromatography on an $\mathrm{Al}_{2} \mathrm{O}_{3}$ column.

About $90 \%$ of the hydrocarbons emitted from the two-stroke moped engine were unburnt fuel hydrocarbons. Benzene, alkylbenzenes and alkenes were virtually absent in the alkylate fuel, making it particularly advantageous for two-stroke and other engines with inefficient combustion. The proportions of combustion-formed hydrocarbons from the alkylate fuel were low for benzene, 1,3-butadiene and ethene and high for methylpropene, as compared with conventional petrol. The combustion products were similar for a lawn mower with a four-stroke engine. Their proportions are explained by the combustion chemistry of the major branched alkylate octanes.

Low exposure levels of the genotoxic components benzene, 1,3-butadiene and ethene make the alkylate fuels especially favourable with respect to health for power saws, gardening machines and mopeds. Low emissions of alkenes and alkylbenzenes make them especially favourable with respect to photooxidant formation for outboard motors and other two-stroke engines used mainly in the critical spring and summer season.
\end{abstract}




\section{INTRODUCTION}

Relationships between the hydrocarbon composition of fuel and exhaust were studied at an early stage with the possibility of decreasing photooxidant formation in mind (Neligan et al., 1961). Since then, the knowledge of the tropospheric reactions of hydrocarbons has increased enormously (Atkinson, 1990). Present extensive plans for regulations with respect to photooxidants have initiated fruitful research on hydrocarbon emissions from the combustion of single-component fuel hydrocarbons (Kaiser et al., 1991). Information on hydrocarbons like benzene and 1,3-butadiene which may be regulated because of severe health effects has been obtained likewise (Siegl et al., 1992).

The alkylation process (Albright, 1990) produces a potentially attractive fuel consisting of highly branched alkanes. Alkylate-based petrol has now been marketed for several years in Sweden for specific purposes such as power saws and lawn mowers. In a previous study, emitted vapours from these fuels were compared with vapours from conventional petrol with high contents of arenes and alkenes (Östermark and Petersson, 1992). The purpose of this continued study was to compare exhaust hydrocarbons in a similar way. A moped was chosen to represent the kind of engines of primary interest for alkylate fuels.

\section{EXPERIMENTAL}

Fuels.

Alkylate-based petrol is marketed in Sweden by Aspen Petroleum and by OK Petroleum. The commercial grades used in this study were Aspen 4T and OK 95 Special. Both are marketed in 51 plastic vessels. The conventional reformate-based grade of petrol studied was OK Optima 95 (unleaded, RON 95). It was obtained from a conventional pump at a service station of the OK chain.

The hydrocarbon composition of the fuels was determined by two different, complementary methods. Conventional GC analysis of liquid samples was performed on a DB-1 methylsilicone FSOT column with split injection and flame ionization detection. Gaseous petrol samples were reliably analyzed by the same technique as the exhaust samples, i. e. by adsorbent sampling followed by gas chromatography. Petrol samples in the $\mu 1$ range were evaporated in a glass vessel (58 1) and gas samples were taken after 2-5 hours.

\section{Moped and lawn mower.}

The test moped was a new ( $400 \mathrm{~km}$ distance driven) Honda PK 50 Wallaroo with an air-cooled, single-cylinder, two-stroke engine ( $49 \mathrm{cc}, 1.2 \mathrm{HP}$ ). The different petrol grades to be used were mixed with $2 \%$ of a conventional motor oil (Castrol super TT). The tank was rinsed twice with the next fuel to be tested, and the moped was driven until fuel-stop after each rinsing. Before test driving, the tank was half-filled and the engine warmed up by 20-30 min of driving. The sampling track was 700-800 $\mathrm{m}$ on plain ground away from other motor traffic. The moped was run with open throttle, resulting in the maximum speed of $30 \mathrm{~km} \mathrm{~h}^{-1}$ allowed in Sweden. The driving direction was chosen to be with rather than against the wind. Sequential samples were taken during driving at 


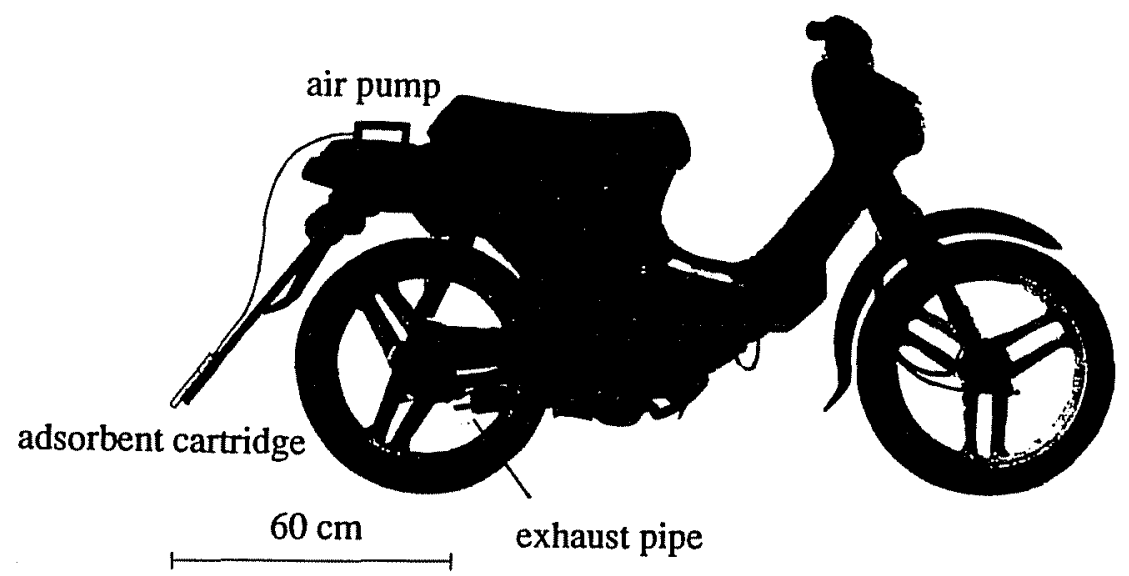

Figure 1. Arrangement of sampling equipment during driving.

$30 \mathrm{~km} \mathrm{~h}^{-1}$ along the sampling track, with idle engine during the intermediate change of sampling cartridge. The sampling device was arranged as illustrated in Figure 1, with the adsorbent cartridge in the mainstream of exhaust.

The walk-behind lawn mower (Stiga Sunline) was equipped with a Briggs and Stratton sidevalve, four-stroke engine (3.5 HP). The tank was rinsed with the petrol to be tested, and the mower was run for $10 \mathrm{~min}$ to warm up the engine. The tank $(1 \mathrm{l})$ was filled with 0.21 of petrol, and each sampling run went on for 15 min with open throttle on a lawn with $5 \mathrm{~cm}$ long grass and without nearby motor traffic. The mowing person carried the sampling pump and had the adsorbent cartridge attached to his chest so as to reflect exhaust exposure.

\section{Sampling and analysis.}

Conventional portable air pumps were used for taking accurately determined air volumes which were in the range 100-200 $\mathrm{ml}$ for most of the samples. The air was passed through triple-layer adsorbent cartridges with Tenax TA (front layer), Carbotrap and Carbosieve S-III as adsorbents of increasing strength. In the laboratory, the hydrocarbons were thermally desorbed into the cold trap of a gas chromatograph. The analytical column was an $\mathrm{Al}_{2} \mathrm{O}_{3}(5 \% \mathrm{KCl})$ PLOT capillary (Chrompack, $50 \mathrm{~m} \times 0.32 \mathrm{~mm}$ i.d.). The oven temperature program was $30{ }^{\circ} \mathrm{C}-110{ }^{\circ} \mathrm{C}\left(10^{\circ} \mathrm{C}\right.$ $\left.\mathrm{min}^{-1}\right), 110^{\circ} \mathrm{C}$ isothermally $(14 \mathrm{~min}), 110^{\circ} \mathrm{C}-200^{\circ} \mathrm{C}\left(4^{\circ} \mathrm{C} \mathrm{min}-1\right)$ and $200^{\circ} \mathrm{C}$ isothermally. The FID response was set equal for all hydrocarbons except for a $5 \%$ correction for the higher response of benzene. The adsorbent cartridges and the analytical system were described in more detail in a previous report (Löfgren et al., 1991).

The identities of the hydrocarbons were determined from their retention data and from mass spectra obtained on a Varian Saturn II ion trap GC-MS intrument. Petrol hydrocarbons were identified on the GC-MS system not only with an alumina column but also with a methylsilicone column which separated the prominent octanes of alkylate petrol.

\section{RESULTS}

Moped. Two-stroke engine.

In Table 1, comparative results are given for a moped fuelled with alkylate-based and with 
Table 1. Non-methane hydrocarbons (\% by weight) in moped exhaust from alkylate-based and reformate-based fuels.

\begin{tabular}{|c|c|c|c|c|c|c|}
\hline \multirow{3}{*}{$\begin{array}{l}\text { Fuel (grade) } \\
\text { Date of sampling }\end{array}$} & \multicolumn{3}{|c|}{ Alkylate (Aspen 4T) } & \multicolumn{3}{|c|}{ Reformate (OK 95, Optima) } \\
\hline & & and 8 Febr, 19 & & & Febr, 1993 & \\
\hline & Exhaust $^{\mathrm{b}}$ & (stand. dev.) & Fuel $^{b}$ & Exhaust $^{c}$ & (stand. dev.) & Fuel $^{\mathrm{c}}$ \\
\hline Benzene & 0.10 & 0.02 & 0.013 & 5.1 & 0.3 & 4.2 \\
\hline Alkylbenzenes & 0.1 & & 0.2 & 49 & & 53 \\
\hline $\begin{array}{l}\text { C7 methylbenzene } \\
\text { C8 ethylbenzene } \\
\text { dimethylbenzenes }\end{array}$ & $\begin{array}{l}0.05 \\
0.01 \\
0.03\end{array}$ & $\begin{array}{l}0.01 \\
0.00 \\
0.01\end{array}$ & $\begin{array}{l}0.08 \\
0.02 \\
0.07\end{array}$ & $\begin{array}{r}15.2 \\
3.2 \\
15.1\end{array}$ & $\begin{array}{l}1.0 \\
0.3 \\
1.5\end{array}$ & $\begin{array}{r}15.1 \\
3.1 \\
14.8\end{array}$ \\
\hline 1,3-Butadiene & 0.10 & 0.03 & 0.00 & 0.11 & 0.03 & 0.00 \\
\hline Alkenes & 9 & & 0.2 & 8 & & 5 \\
\hline $\begin{array}{l}\text { C2 } \text { ethene } \\
\text { C3 propene } \\
\text { C4 trans-2-butene } \\
\text { 1-butene } \\
\text { methylpropene } \\
\text { cis-2-butene } \\
\text { C5 3-methyl-1-butene } \\
\text { trans-2-pentene } \\
\text { 2-methyl-2-butene } \\
\text { 1-pentene } \\
\text { 2-methyl-1-butene } \\
\text { cis-2-pentene } \\
\text { C6 hexenes }\end{array}$ & $\begin{array}{l}2.1 \\
2.6 \\
0.22 \\
0.20 \\
2.1 \\
0.16 \\
0.09 \\
0.04 \\
0.45 \\
0.06 \\
0.16 \\
0.02 \\
0.29\end{array}$ & $\begin{array}{l}0.6 \\
0.5 \\
0.04 \\
0.04 \\
0.4 \\
0.03 \\
0.02 \\
0.01 \\
0.07 \\
0.01 \\
0.03 \\
0.01 \\
0.05\end{array}$ & $\begin{array}{l}0.00 \\
0.00 \\
0.00 \\
0.00 \\
0.03 \\
0.00 \\
0.00 \\
0.02 \\
0.02 \\
0.00 \\
0.00 \\
0.01 \\
0.05\end{array}$ & $\begin{array}{l}1.9 \\
1.0 \\
0.15 \\
0.22 \\
0.41 \\
0.14 \\
0.06 \\
0.37 \\
0.52 \\
0.23 \\
0.35 \\
0.22 \\
1.7\end{array}$ & $\begin{array}{l}0.5 \\
0.3 \\
0.03 \\
0.06 \\
0.1 \\
0.02 \\
0.01 \\
0.05 \\
0.06 \\
0.02 \\
0.07 \\
0.03 \\
0.3\end{array}$ & $\begin{array}{l}0.00 \\
0.00 \\
0.13 \\
0.03 \\
0.05 \\
0.12 \\
0.05 \\
0.44 \\
0.63 \\
0.19 \\
0.32 \\
0.24 \\
1.8\end{array}$ \\
\hline Ethyne & 1.6 & 0.3 & 0.00 & 1.8 & 0.3 & 0.00 \\
\hline Alkanes & 88 & & 99 & 33 & & 36 \\
\hline $\begin{array}{l}\text { C4 methylpropane } \\
\text { butane } \\
\text { C5 methylbutane } \\
\text { pentane } \\
\text { C6 2,3-dimethylbutane } \\
\text { 2-methylpentane } \\
\text { 3-methylpentane } \\
\text { hexane } \\
\text { C7 2,4-dimethylpentane } \\
\text { other heptanes } \\
\text { C8 2,2,4-trimethylpentane } \\
\text { other octanes }\end{array}$ & $\begin{array}{l}1.1 \\
4.7 \\
2.7 \\
0.10 \\
1.2 \\
0.59 \\
0.30 \\
0.12 \\
2.0 \\
1.4 \\
35 \\
32\end{array}$ & $\begin{array}{l}0.1 \\
0.6 \\
0.3 \\
0.02 \\
0.07 \\
0.05 \\
0.04 \\
0.02 \\
0.05 \\
0.05 \\
1.6 \\
1.1\end{array}$ & $\begin{array}{l}1.3 \\
7.2 \\
3.6 \\
0.02 \\
1.5 \\
0.5 \\
0.3 \\
0.01 \\
1.9 \\
1.3 \\
37 \\
34\end{array}$ & $\begin{array}{l}2.0 \\
3.9 \\
6.3 \\
2.3 \\
0.48 \\
3.4 \\
2.4 \\
1.8 \\
0.31 \\
4.6 \\
0.07 \\
2.3\end{array}$ & $\begin{array}{l}0.4 \\
0.8 \\
1.0 \\
0.3 \\
0.03 \\
0.2 \\
0.2 \\
0.2 \\
0.03 \\
0.3 \\
0.01 \\
0.2\end{array}$ & $\begin{array}{l}2.2 \\
5.2 \\
7.2 \\
2.6 \\
0.6 \\
3.6 \\
2.5 \\
1.9 \\
0.3 \\
4.5 \\
0.1 \\
2.3\end{array}$ \\
\hline
\end{tabular}

a 5 Febr - 3 samples, $2^{\circ} \mathrm{C}$, moderate wind; 8 Febr -4 samples, $5^{\circ} \mathrm{C}$, very weak wind; $17 \mathrm{Febr}-6$ samples, $3^{\circ} \mathrm{C}$, weak wind.

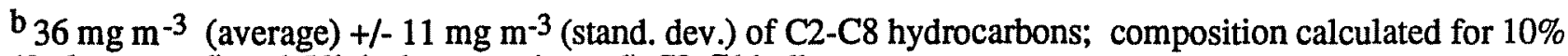
(fuel, assessed) and 5\% (exhaust, estimated) $\mathrm{C} 9-\mathrm{C} 11$ alkanes.

$c 47 \mathrm{mg} \mathrm{m}^{-3}$ (average) $+/-26 \mathrm{mg} \mathrm{m}^{-3}$ (stand. dev.) of C2-C8 hydrocarbons; composition calculated for $20 \%$ (fuel, assessed) and 15\% (exhaust, estimated) C9-C10 arenes. 
Table 2. Exposure to hazardous hydrocarbons from a lawn mower run on different fuels. ${ }^{\mathrm{a}}$

\begin{tabular}{|c|c|c|c|c|c|c|}
\hline $\begin{array}{l}\text { Fuel } \\
\text { Grade } \\
\text { Date (1992) } \\
\text { Sampling }\end{array}$ & $\begin{array}{c}\text { Alkylate } \\
\text { Aspen 4T } \\
30 \text { July } \\
\text { mower } \\
\text { \%NMHC }\end{array}$ & $\begin{array}{l}\text { Alkylate } \\
95 \text { Special } \\
30 \text { July } \\
\text { mower } \\
\text { \%NMHC }\end{array}$ & $\begin{array}{c}\text { Reformate } \\
\text { OK } 95 \\
31 \text { July } \\
\text { mower } \\
\text { \%NMHC }\end{array}$ & $\begin{array}{c}23 \text { Sept } \\
\text { in car } \\
\% \mathrm{NMHC}\end{array}$ & $\begin{array}{l}\text { Alkylate } \\
95 \text { Special } \\
30 \mathrm{July} \\
\text { mower } \\
\mu \mathrm{g} \mathrm{m}^{-3}\end{array}$ & $\begin{array}{c}23 \mathrm{Sept} \\
\text { in car } \\
\mu \mathrm{g} \mathrm{m}^{-3}\end{array}$ \\
\hline benzene & 0.5 & 0.5 & 7 & 8 & 6 & 35 \\
\hline methylbenzene & 0.3 & 0.4 & 16 & 14 & 5 & 62 \\
\hline 1,3-butadiene & 0.3 & 0.4 & 0.3 & 0.4 & 4 & 2 \\
\hline ethene & 8 & 7 & 5 & 4 & 80 & 18 \\
\hline propene & 7 & 6 & 2 & 2 & 70 & 9 \\
\hline methylpropene & 5 & 5 & 1 & 0.8 & 60 & 4 \\
\hline hexane & 0.2 & 0.3 & 1.4 & 2 & 3 & 9 \\
\hline 2,2,4-trimethylpentane & 23 & 23 & 0.3 & 0.2 & 300 & 1 \\
\hline
\end{tabular}

${ }^{\text {a }}$ Compared with exposure inside a car in urban traffic (Barrefors and Petersson, 1993).

reformate-based petrol. The average percent composition of non-methane exhaust hydrocarbons is given for seven (alkylate) and six (reformate) evening test runs with warm engine at an even speed $\left(30 \mathrm{~km} \mathrm{~h}^{-1}\right)$ along the same selected remote test track. The high absolute concentrations resulting from the position of the device (Figure 1) permitted minor components to be determined and contributions from surrounding air to be neglected. It should be observed that the standard deviation reflects not only analytical precision but primarily differences in exhaust composition between the samples. The reported fuel composition was determined from gaseous samples and checked by complementary conventional GC analysis of liquid samples.

The hydrocarbon content is extremely different between the two fuels. The alkylate-based petrol consists almost exclusively of alkanes. Branched octanes constitute $70 \%$ with $35 \%$ for the well-known major isomer 2,2,4-trimethylpentane (isooctane). Benzene, alkylbenzenes and alkenes are almost absent. In sharp contrast, the reformate-based petrol contains $4 \%$ benzene, more than $50 \%$ alkylbenzenes, and 5\% alkenes. The $\mathrm{C}_{6}-\mathrm{C}_{8}$ alkanes differ from those of alkylate petrol by a much higher proportion of unbranched and monomethylbranched isomers and a much lower proportion of highly branched isomers.

The exhaust hydrocarbons consist mainly $(90 \%)$ of unburnt fuel hydrocarbons because of the inefficient combustion of the two-stroke engine. Their proportions are similar to those in the fuel. The major combustion-formed hydrocarbons (ethene, propene, methylpropene, ethyne) add up to $8 \%$ for the alkylate petrol and $5 \%$ for the reformate petrol. Combustion-formed benzene adds significantly for the reformate petrol.

Lawn mower. Four-stroke engine.

Comparative results for lawn mower exhaust are given in Table 2 for hydrocarbons of particular 


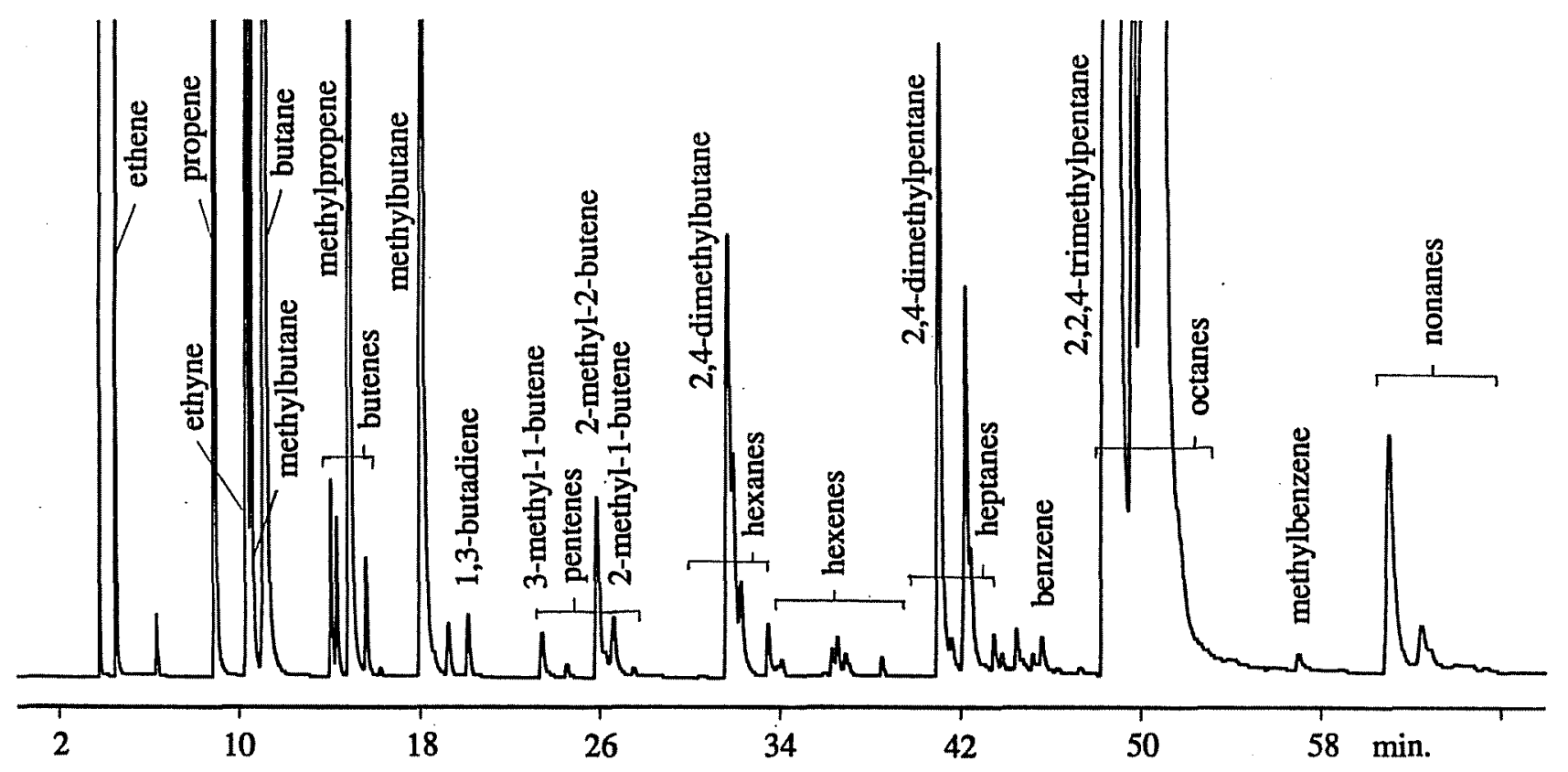

Figure 2. Gas chromatographic separation (on an $\mathrm{Al}_{2} \mathrm{O}_{3}$ column) of hydrocarbons in exhaust behind a moped fuelled with alkylate petrol.

interest. The more efficient combustion of the four-stroke engine gives rise to lower percentages of fuel alkanes and higher percentages of combustion-formed hydrocarbons, as compared with moped exhaust. The two different alkylate-based fuels give rise to similar hydrocarbon proportions.

The hydrocarbon proportions of exhaust from the reformate-based petrol are quite similar to those of vehicle-polluted urban air inside a car in urban traffic. This is explained by a predominance of reformate-based petrol in the Göteborg region.

The last two columns of Table 2 compare exposure levels when running an alkylate-fuelled walk-behind mower and when driving a car in urban traffic. On mowing, significant portions of benzene, methylbenzene and hexane may be due to background air pollution because of the very low proportions of these hydrocarbons in alkylate exhaust. The background levels in the moped test area were $2 \mu \mathrm{g} \mathrm{m}^{-3}$ for benzene, $2 \mu \mathrm{g} \mathrm{m}^{-3}$ for methylbenzene and $0.3 \mu \mathrm{g} \mathrm{m}^{-3}$ for hexane.

\section{DISCUSSION}

\section{Analytical methods.}

The chromatogram reproduced in Figure 2 visualizes the hydrocarbon composition of moped exhaust from alkylate-based petrol. The alumina column favourably separates $C_{n}$ alkenes from $C_{n}$ alkanes, and all isomers are eluted within a narrow range, as indicated in the chromatogram. Specific hydrocarbons of particular interest are marked. The clear-cut separation of ethene, propene, butenes, 1,3-butadiene, benzene and methylbenzene is important in environmental contexts.

Adsorbent sampling of non-methane volatile hydrocarbons in combination with thermal desorption and gas chromatography on an $\mathrm{Al}_{2} \mathrm{O}_{3}$ column offers great analytical versatility (Löfgren et al., 1991). Previous applications with illustrative chromatograms include studies of vehicle- 


\begin{tabular}{|c|c|c|}
\hline methylpropene ! | propene & \begin{tabular}{r|c} 
& 2-methyl-2-butene \\
& 3-methyl-1-butene \\
propene & i propene
\end{tabular} & $\begin{array}{l:ll} & \\
\text { propene } & \text { ethene }\end{array}$ \\
\hline $\begin{array}{c}\mathrm{CH}_{3} \quad \mathrm{CH}_{3} \\
\mathrm{CH}_{3}-\stackrel{1}{\mathrm{C}}-\mathrm{CH}_{2}-\mathrm{CH}-\mathrm{CH}_{3} \\
\stackrel{\mathrm{C}}{\mathrm{C}} \mathrm{C}_{3} \\
\text { methylpropene }\end{array}$ & $\begin{aligned} \mathrm{CH}_{3} \mathrm{CH}_{3} \mathrm{CH}_{3} \\
\mathrm{CH}_{3}-\stackrel{\mathrm{CH}}{\mathrm{C}} \mathrm{CH}-\stackrel{\mathrm{CH}}{\mathrm{C}}-\mathrm{CH}_{3} \\
\text { 3-methyl-1-butene } \\
\text { 2-methyl-2-butene }\end{aligned}$ & $\begin{array}{c}\mathrm{CH}_{3} \mathrm{CH}_{3} \\
\mathrm{CH}_{3}-\mathrm{CH}-\mathrm{C}-\mathrm{CH}_{2}-\mathrm{CH}_{3} \\
\stackrel{1}{\mathrm{C}} \mathrm{H}_{3} \\
\text { 2-methyl-1-butene }\end{array}$ \\
\hline
\end{tabular}

Figure 3. Alkenes $\left(C_{2}-C_{5}\right)$ formed during combustion, by hydrogen abstraction and $B$ scission, from the three major octane isomers of the alkylate fuels.

polluted urban air (Löfgren and Petersson, 1992), of exposure to petrol vapours during refuelling (Östermark and Petersson, 1992), and of environmental tobacco smoke (Barrefors and Petersson, 1993). The alumina column has also been used for analysis of gaseous samples of bag-collected exhaust hydrocarbons (Pelz et al., 1990).

With the low sampling volumes and the low ambient temperatures of the moped study, no break-through losses occurred for ethyne which was previously found to be the least strongly adsorbed non-methane hydrocarbon. Recovery of the easily decomposed 2-methyl-2-butene (Löfgren et al., 1991) indicated negligible losses of reactive hydrocarbons.

\section{Combustion chemistry.}

From Tables 1 and 2, it is evident that the alkylate-based fuels give rise to specific proportions between the combustion-formed hydrocarbons. Three trimethylpentanes (Figure 3) made up 60\% of the fuel hydrocarbons, and their combustion chemistry is related to the product mixture formed. The 2,2,4-trimethyl-, 2,3,4-trimethyl-, and 2,3,3-trimethylpentanes constituted approximately 50\%, $20 \%$ and $10 \%$ of the total alkylate octanes. Prominent combustion reactions of hydrocarbons involve an initial hydrogen abstraction followed by B-cleavage to form an alkene and an alkyl radical (Dryer and Brezinsky, 1986). As outlined in Figure 3, these reactions explain the very high proportion of methylpropene and the high proportion of propene from alkylate-based petrol. The unusually high proportion of 3-methyl-1-butene and the formation of 2-methyl-2-butene and 2methyl-1-butene are also consistent with the octane structures. The alkylate exhaust samples clearly display combustion-formed alkenes (Figure 2) since the fuel is almost free of alkenes.

The unbranched or little branched alkanes of conventional fuels give rise to ethene as the most prominent alkene. A comparative combustion study of 2,2,4-trimethylpentane and octane (Dryer and Brezinsky, 1986) clearly demonstrates the differences in combustion products and combustion chemistry. Combustion studies of pure hydrocarbons also reveal significant formation of benzene from methylbenzene (Kaiser et al., 1991) and of benzene and methylbenzene from $\mathrm{C}_{8}$ alkylbenzenes (Kaiser et al., 1992). The same studies demonstrate that little benzene is formed from alkanes and very low amounts of alkenes from $\mathrm{C}_{7}-\mathrm{C}_{8}$ alkylbenzenes. Accordingly, the results of Table 1 indicate combustion-formed benzene of the order of $0.1 \%$ and $1 \%$, depending on whether the moped is fuelled with alkylate-based or reformate-based petrol. 
Total hydrocarbon emissions from experimental combustion of pure hydrocarbons increase significantly in the order unbranched alkane $<2,2,4$-trimethylpentane $<$ methylbenzene (Kaiser et al., 1991; Siegl et al., 1992). The total NMHC concentrations given below Table 1 are influenced by weather and wind and indicate the order of magnitude only. Judging from the high arene content of the reformate fuel, it should cause higher total exhaust emissions than the alkylate fuel.

\section{Health hazards.}

The established genotoxic health hazards of benzene and 1,3-butadiene are already considered in work with emission standards and new fuels (Siegl et al., 1992). A third exhaust-emitted hydrocarbon of great genotoxic concern is ethene (Törnqvist and Ehrenberg, 1990). All alkenes are potentially genotoxic because of metabolic formation of epoxides. Both alkenes and alkylbenzenes are regarded as more toxic than alkanes. Environmental classification and taxation of fuels according to the content of benzene, alkylbenzenes and alkenes is planned in Sweden. Hexane stands out among the alkanes as specifically neurotoxic (Perbellini et al., 1980).

The content of benzene and alkylbenzenes in the marketed alkylate-based fuels has been successively lowered since their introduction in Sweden five years ago. From Table 1, it is seen that a benzene content as low as $0.01 \%$ has now been achieved. The remarkably higher content of $4 \%$ in the reformate fuel is reflected in emitted vapours and unburnt exhaust hydrocarbons. Furthermore, the additional combustion-formed amount of exhaust benzene is one order of magnitude larger for the reformate fuel.

The content of 1,3-butadiene is low in alkylate exhaust because of the very low content $(<0.1 \%)$ in the fuel of cyclohexanes which give rise to 1,3-butadiene on combustion (Kaiser et al., 1992). The content of ethene is low because the highly branched alkanes of the alkylate fuel give rise primarily to methylpropene and propene. The reformate-based fuel studied gives rise to low proportions of 1,3-butadiene and ethene because of its high arene content as compared with average conventional fuels.

The results given in Tables 1 and 2 demonstrate a remarkable superiority of the alkylate fuels when the exhaust proportions of all the hazardous hydrocarbons are compared with the proportions resulting from conventional fuels. The health arguments for alkylate fuels are further strengthened by the large differences in health hazards for vapour hydrocarbons (Östermark and Petersson, 1992).

\section{Environmental aspects.}

Hydrocarbons give rise to photooxidants which represent serious threats to both vegetation and human health. The most reactive hydrocarbons which cause high first-day photooxidant concentrations are of greatest concern. Alkenes and alkylbenzenes belong to these hydrocarbons, whereas alkanes are less reactive (Atkinson, 1990). High emissions of alkylbenzenes, especially from cold starts and from two-stroke engines, make reformate fuels worse than alkylate fuels with regard to photooxidants. The reformate fuel studied illustrates that a high content of alkylbenzenes is often used to compensate for the lowered RON number of unleaded petrol. Benzene and alkylbenzenes from spills of reformate fuel are also more toxic to aquatic organisms than alkylate hydrocarbons.

The combustion-formed alkenes from alkylate fuels are mainly $\mathrm{C}_{2}-\mathrm{C}_{4}$ 1-alkenes which are the 
least reactive alkenes in photooxidant formation. The fuel alkenes in conventional petrol are mainly reactive $\mathrm{C}_{4}-\mathrm{C}_{6}$ species with a large proportion of the particularly reactive $\mathrm{C}_{4}-\mathrm{C}_{5}$ 2-alkenes (Östermark and Petersson, 1992) and $\mathrm{C}_{6} 2$ - and 3-alkenes (Ramnäs et al., 1993). The most reactive $\mathrm{C}_{4}-\mathrm{C}_{6}$ alkenes were early known to produce eye-irritating oxidants (Neligan et al., 1961), and the differences in tropospheric reactions are now well known (Atkinson, 1990). It is concluded that alkenes in alkylate exhaust are less reactive than alkenes in exhaust from conventional petrol. Petrol with a high content of alkenes from cat-cracked naphtha is likely to be the worst alternative with regard to photooxidants formed from vapours (Östermark and Petersson, 1992) as well as from exhaust (Neligan et al., 1961).

\section{Specific uses of alkylate fuels.}

The differences in hydrocarbon emissions provide strong environmental reasons and even stronger health reasons for a shift from conventional petrol to alkylate petrol. Combustion results for model hydrocarbons indicate that $\mathrm{NO}_{\mathrm{x}}$ emissions may be somewhat lower as well (Kaiser et al., 1991). Technical production limitations permit gradually expanded consumption only. Applications involving a high human uptake of emitted hydrocarbons should be primary targets. Two-stroke and other engines with large emissions relative to consumed amount of fuel should be given a high priority. An early shift to alkylate fuels is also essential for applications which cause emissions concentrated in time to the spring and summer photooxidant season.

The alkylate fuels already prevail for power saws in Sweden. This is essential because of the high exposure and high lung ventilation of forest workers. Similar arguments for a shift to alkylate fuels apply to a wide range of other two-stroke working machines with engines and emissions very near to the operator. Many gardening machines are used mainly in the critical photooxidant season. Mopeds, scooters and other vehicles with two-stroke engines emit much larger amounts of hydrocarbons than cars relative to the fuel consumption. Mopeds on cycle tracks expose cyclists with their high lung ventilation to unwanted hydrocarbons. A major portion of fuel for two-stroke engines is used for outboard motors. Their emissions occur mainly in spring and summer in coastal regions where photooxidant formation and effects are severe. Conventional exhaust emissions of hydrocarbons to water may also cause toxic effects from benzene and alkylbenzenes on aquatic life. Alkylate petrol is already widely used in the vulnerable Norwegian fjords and is presently beeing made commercially available along the Swedish coast.

Lawn mowers have four-stroke engines with exhaust hydrocarbon emissions which are an order of magnitude lower than those of the two-stroke engines discussed. On the other hand, the emissions are an order of magnitude higher than those of cars relative to fuel consumption. Furthermore, emissions of both vapour and exhaust hydrocarbons occur just in front of the operator and predominantly during the photooxidant season. Alkylate fuel is therefore the proper choice for walk-behind mowers and is already much used in Sweden.

Alkylate fuels are technically attractive for cars because of high RON levels and a very low content of alkenes which may cause engine deposits. The Swedish automotive industry uses alkylate petrol as the critical initial fuel in new cars. Traditionally, available alkylate is mixed into and improves the technical quality of conventional petrol for cars (Albright, 1990). Regarding environment and health, it is evident that the discussed specific uses of alkylate fuels should be given the highest priority. Alkylate-based fuels may also gradually involve the car market. In 
Göteborg, one of the largest taxi chains pioneers by large-scale use of an ethanol-blended alkylate fuel.

\section{REFERENCES}

Albright L. F. (1990). Alkylation will be key process in reformulated gasoline era. Oil Gas J.88 (46), 79-92.

Atkinson R. (1990). Gas-phase tropospheric chemistry of organic compounds: A review. Atmos. Environ. 24A, 1-41.

Barrefors G. and Petersson G. (1993). Assessment of ambient volatile hydrocarbons from tobacco smoke and from vehicle emissions. J. Chromatogr., in press.

Dryer F. L. and Brezinsky K. (1986). A flow reactor study of the oxidation of n-octane and isooctane. Combust. Sci. Tech. 45, 199-212.

Kaiser E. W., Siegl W.O., Henig Y.I., Anderson R. W. and Trinker F. H. (1991). Effect of fuel structure on emissions from a spark-ignited engine. Environ. Sci. Technol. 25, 2005-2012.

Kaiser E. W., Siegl W.O., Cotton D. E. and Anderson R. W. (1992). Effect of fuel structure on emissions from a spark-ignited engine. 2. Naphtene and aromatic fuels. Environ. Sci. Technol. 26, 1581-1586.

Löfgren L., Berglund P. M., Nordlinder R., Petersson G. and Ramnäs O. (1991). Selective assessment of $\mathrm{C}_{2}-\mathrm{C}_{6}$ alkenes in air by adsorption sampling and gas chromatography. Int. J. Environ. Anal. Chem. 45, 39-44.

Löfgren L. and Petersson G. (1992). Proportions of volatile hazardous hydrocarbons in vehiclepolluted urban air. Chemosphere 24, 135-140.

Neligan R. E., Mader P. P. and Chambers L. A. (1961). Exhaust composition in relation to fuel composition. JAPCA 11, 178-186.

Pelz N., Dempster N. M. and Shore P.R. (1990). Analysis of low molecular weight hydrocarbons including 1,3-butadiene in engine exhaust gases using an aluminum oxide porous-layer open tubular fused-silica column. J. Chromatogr. Sci. 28, 230-235.

Perbellini L., Brugnone F. and Pavan I. (1980). Identification of the metabolites of n-hexane, cyclohexane and their isomers in men's urine. Toxicol. Appl. Pharmacol. 53, 220-229.

Ramnäs O., Östermark U. and Petersson G. (1993). Assessment by GC-MS of hexenes emitted to air from petrol. J. Chromatogr., in press.

Siegl W. O., McCabe R. W., Chun W., Trinker F. H. and Anderson R. W. (1992). Speciated hydrocarbon emissions from the combustion of single component fuels. 1. Effect of fuel structure. J. Air Waste Manage. Assoc. 42, 912-920.

Östermark U. and Petersson G. (1992). Assessment of hydrocarbons in vapours of conventional and alkylate-based petrol. Chemospere $25,763-768$. 